\title{
Article
}

\section{Akuntabilitas Publik Anggota DPRD Kabupaten Tebo Terhadap Konstituennya}

\author{
Siti Maryam J ${ }^{1 *}$, Bambang Nugroho ${ }^{2}$
}

This article is an open access article distributed under the terms and conditions of the Creative Commons Attribution-ShareAlike 4.0 International (CC BY SA ) License (https://creativecommo ns.org/licenses/by$\underline{\mathrm{sa} / 4.0 /) \text {. }}$

\section{Jurnal Politik dan} Pemerintahan Daerah ISSN 2686-2271

Fakultas Ilmu Sosial dan Ilmu Politik, Universitas Muara Bungo Jl. Diponegoro No. 27, Muara Bungo-Jambi, (0747) 323310

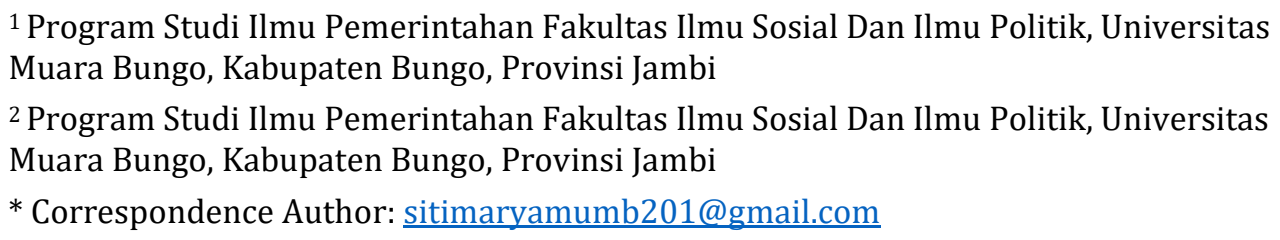

Abstract: The principle of accountability is used to create an effective control system based on the distribution of power. So in general definition, public accountability is the obligation of the trust holder to provide accountability, present, report, and disclose all activities and activities that are the responsibility of the party providing the mandate. Politics is a concept where there is a legitimate way to gain, maintain, or legalize legitimacy which of course cannot be far away in reality in our daily lives, both from the village level to the presidential election though, not to mention the district level legislative elections. In politics, all elements cannot be avoided from a competition, starting from the party itself, participants/candidates, and community support groups. So from there will be born a leader or representative of a certain community group. In political parties there is a party mechanism that must be followed, on the other hand there are people who vote for them with promises or work programs that have long been proclaimed during the campaign in the form of socialization to the community. Besides that, there are high political costs and excessive loyalty to the voting community during elections, such as the provision of untimely infrastructure facilities, money politics, and others, all of which are aimed at getting people to vote for them. change the mindset of the community so that it progresses and develops forward. The council's public accountability lies not only in its remuneration to its constituents by providing public facilities for the continuity and smooth running of the economy in its territory, but also in the form of transparency, consolidation, and accountability for what they have done for their constituents.

Keywords: Political Promises of Council Members, Constituents, Accountability Process

Abstrak: Prinsip akuntabilitas digunakan untuk menciptakan sistem kontrol yang efektif berdasarkan distribusi kekuasaan. Jadi secara definisi umum akuntabilitas publik adalah kewajiban pihak pemegang amanah untuk memberikan pertanggungjawaban, menyajikan, melaporkan, dan mengungkapkan segala aktivitas dan kegiatan yang menjadi tanggungjawab kepada pihak yang memberikan amanah. Politik merupakan sebuah konsep dimana cara yang sah untuk mendapatkan, mempertahankan, atau melegalkan legitimasi yang sudah tentu tidak bisa jauh-jauh realitanya dikehidupan sekitar kita sehari-hari baik dari tingkat Desa sampai pemilu presiden sekalipun, tidak terkecuali pemilu legislatif tingkat Kabupaten. Dalam politik semua elemen tidak bisa dihindarkan dari sebuah kompetisi baik mulai dari partainya sendiri, peserta/kandidat, dan masyarakat kelompok pendukung. Maka dari situlah akan lahir sebuah pemimpin atau perwakilan dari sebuah kelompok masyarakat tertentu. Dalam partai politik ada mekanisme partai yang harus ikuti, disisi lain ada rakyat yang memilihnya dengan janji -janji atau program kerja yang sudah jauh-jauh 
hari dicanangkan pada waktu kampanye dalam bentuk sosialisasi kepada masyarakat. Disamping itu adanya ongkos politik yang mahal dan loyalitas yang berlebihan kepada masyarakat pemilih diwaktu pemilu berjalan seperti pemberian sarana infrastruktur yang belum waktunya, money politik, dan lainnya yang kesemuanya itu bertujuan agar masyarakat memilihnya seharusnya proses itu dilakukan dengan perang adu gagasan atau ide-ide untuk merubah pola pikir masyarakat agar maju serta berkembang maju. Akuntabilitas publik dewan bukan hanya terletak balas jasanya kepada konstituen memberikan sarana publik untuk kelangsungan dan kelancaran jalannya perekonomian diwilayahnya, akan tetapi bentuk transparansi, konsilidasi, serta pertanggungjawaban tentang apa saja yang sudah mereka perbuat untuk konstituennya.

Kata kunci: Janji Politik Anggota Dewan, Konstituen, Proses Pertanggungjawaban

\section{Pendahuluan}

Akuntabilitas sebagai salah satu prinsip good governance berkaitan dengan pertanggungjawaban pimpinan atas keputusan dan hasil yang dicapai sesuai dengan wewenang yang dilimpahkan dengan pelaksanaan tanggung jawabnya. Prinsip akuntabilitas digunakan untuk menciptakan sistem kontrol yang efektif berdasarkan distribusi kekuasaan. Jadi secara definisi umum akuntabilitas publik adalah kewajiban pihak pemegang amanah untuk memberikan pertanggungjawaban, menyajikan, melaporkan, dan mengungkapkan segala aktivitas dan kegiatan yang menjadi tanggungjawab kepada pihak yang memberikan amanah. Dengan adanya pelaksanaan otonomi daerah di Indonesia pada tahun 2001, tercipta jenis akuntabilitas baru yang tertuang dalam UU Nomor 22 tahun 1999 dan UU no 25 tahun 1999 (Sadjiarto, 2000).

Terkait dengan topik peneliti yaitu tentang "Akuntabilitas Publik Anggota DPRD Kabupaten Tebo Terhadap Konstituennya" untuk dapil II Kecamatan Rimbo Ilir, maka sudah tentu peneliti akan membahas tentang apa bentuk akuntabilitas anggota DPRD selama ini dalam kinerjanya terhadap konstituen atau masyarakat yang sudah memilihnya. Akuntabilitas merupakan suatu konsep yang diharapkan dalam penerapannya mampu memberikan penjelasan atas tindakan yang dilakukan oleh sebuah organisasi kepada pihak-pihak yang diberikan wewenang untuk melakukan pemeriksaan dan evaluasi pada organisasi tersebut (Wicaksono, 2015) Akuntabilitas dipandang penting dalam sebuah organisasi baik dalam pemerintahan maupun non pemerintahan. Akuntabilitas merupakan sebuah istilah yang sering digunakan dalam teori dan praktik dalam dunia pemerintahan dan politik (Kholmi, 2011). Politik merupakan sebuah konsep dimana cara yang sah untuk mendapatkan, mempertahankan, atau melegalkan legitimasi yang sudah tentu tidak bisa jauh-jauh realitanya dikehidupan sekitar kita sehari-hari baik dari tingkat Desa sampai pemilu presiden sekalipun, tidak terkecuali pemilu legislatif tingkat Kabupaten. Dalam politik semua elemen tidak bisa dihindarkan dari sebuah kompetisi baik mulai dari partainya sendiri, peserta/kandidat, dan masyarakat kelompok pendukung.

Maka dari situlah akan lahir sebuah pemimpin atau perwakilan dari sebuah kelompok masyarakat tertentu. Jika melihat atau mendengar nama Kabupaten Tebo adalah merupakan salah satu Kabupaten yang masuk kategori tidak terisolir atau tertinggal lagi walaupun juga belum bisa dikatakan daerah maju, disetiap Kabupaten manapun tentu dalam legislatifnya ada salah satu partai yang dominan berkuasa dalam arti kata lain mempunyai perwakilan terbanyak ditingkat DPRD begitu pula di Kabupaten Tebo. 
Selanjutnya bagaimana sebenarnya proses akuntabilitas publik para anggota DPRD selama ini, sudahkah sejalan sebagaimana mestinya karena yang banyak terjadi justru timbul stikma bahwa para anggota DPRD justru lebih loyalitas terhadap partainya ketimbang kontituennya, lebih dominan jadi wakil partainya ketimbang wakil rakyatnya, faktual atau tidaknya statements diatas tentu tugas peneliti yang akan menganalisa nantinya. Memang jika melihat peran dewan diranah legislatif mereka dibebani dua peran yaitu wakil dari partainya sekaligus wakil dari konstituen atau daerah pilihannya (dapil). Jika realita tersebut menjadi hal yang dilema bagi mereka (para anggota DPRD) menjadi wajar karena setelah mereka duduk ada perahu yang membawanya yaitu partai politik tersebut ada mekanisme partai yang mereka ikuti sebelumnya, disisi lain ada rakyat yang memilihnya dengan janji -janji atau program kerja yang sudah jauh-jauh hari dicanangkan pada waktu kampanye dalam bentuk sosialisasi kepada masyarakat. Dalam permasalahan dapil II untuk wilayah Kecamatan Rimbo Ilir itu peneliti mengambil 3 nama anggota dewan terpilih yaitu saudarai Pahlepi dari partai Demokrat, Karno dari partai Gerindra, dan Rosmalena dari partai Golkar.

Ketiganya adalah wakil dari dapil II, Ketiga tentu ketika dimasa kampanye mempunyai resolusi yang ditawarkan kepada konstituennya baik berbentuk janji politik, kontrak politik, maupun misi dan visinya. Ketiga resolusi yang penulis sebutkan mungkin hampir sama maknanya hanya mempunyai perbedaanperbedaan yang tipis, masalah janji politik adalah hal yang dijanjikan kepada konstituen agar mendapat simpati untuk memilihnya berupa program kegiatan pembangunan fisik maupun non fisik. Kontrak politik merupakan alternatif penawaran kepada konstituen disuatu bagian Desa misalnya yang khusus biasanya berupa pembangunan fisik sudah akan diberikan serta dibangun meski masih dimasa kampanye dalam makna lain adalah bisa disebut upaya memaksa namun dengan memberikan imbalan kepada konstituen terlebih dahulu, sementara untuk visi misi sudah menjadi hal yang lumrah dan sewajarnya.

Untuk dapil II Kec. Rimbo Ilir mempunyai 7 perwakilan anggota namun 4 diantaranya adalah tidak sedang tinggal atau berasal dari Rimbo Ilir jadi secara otomatis mereka hanya punya dua wakil saja. Karena sudah menjadi wajar jika anggota yang memiliki jumlah suara terbanyak di Kecamatan A misalnya anggota tersebut juga akan memihak, mementingkan aspirasi dalam masalah pembangunan atau perekonomian wilayah A tersebut. Mesti dalam aturan mereka boleh membangun di Kecamatan lain selagi dalam satu dapil. Akan tetapi kita harus melihat realita bahwa unsur balas jasa politik adalah suara terbanyak, akuntabilitas seorang anggota DPRD juga harus sebanding dengan kinerjanya dilegislatif agar masyarakat mengetahui berapa porsi mereka untuk rakyatnya.

Jadi tentu tidak semua anggota dewan memiliki porsi dan hak yang sama untuk mendapatkan prioritas program karena ada hal non tehnis yang mempengaruhi kebijakan seperti, jumlah kursi dalam partainya, unsur kedekatan koalisi partai dengan pimpinan dewan, kemampuan berkonsilidasi dengan pihak terkait, dan lainnya. Berbicara tentang akuntabilitas publik anggota DPRD terhadap kontituen tentu juga menyangkut transparasi dan bentuk partisipasi kontituennya, di Kecamatan Rimbo Ilir Kabupaten Tebo khususnya juga belum ada sistem yang mengatur bahwa setiap anggota dewan harus punya bentuk pertanggungjawaban kepada kontituennya selama mereka bekerja atas apa yang sudah mereka kontribusikan untuk daerah pemilihannya. Keadaan justru berbanding terbalik ketika anggota DPRD mempunyai bentuk pertanggungjawaban kepada partainya sedangkan kontituen tidak kalah penting dan prioritas. Misal setiap anggota dewan terkait disetiap wilayah pemilihannya tidak punya semacam rumah aspirasi untuk menampung aspirasi masyarakat bawah tentang apa yang menjadi bentuk keinginan dan harapan masyarakat yang sudah memilihnya. 
Selama hal ini penyampaian aspirasi terjadi melalui mekanisme musyawarah-musyawarah dan pengajuan musrenbang yang kita sudah sama-sama lihat persentase realisasinya sangat kecil. Bentuk transparansi, peranan, dan akuntabilitas anggota dewan lain yang minim yaitu dalam hal penyusunan APBD sangat kecil, apalagi peran masyarakat yang dilibatkan, dewan terkesan hanya memberikan pengesahan atas RAPBD yang diajuakan esksekutif. Seharusnya peran DPRD harus mampu menyajikan informasi penyelenggaraan pemerintah secara terbuka, cepat, dan tepat kepada masyarakat, mampu memberikan ruang kepada masyarakat untuk terlibat dalam proses pembangunan dan pemerintah, mampu menjelaskan dan mempertanggujawabkan setiap kebijakan publik secara proporsional, serta terakhir adanya suara bagi publik untuk menilai kinerja pemerintah. Melalui pertanggungjawaban publik masyarakat dapat menilai derajat pencapaian pelaksanan program dari wakilnya di legislatif bahkan pemerintahan secara umum.

Yang umum terjadi justru setelah adanya pemilu legislatif kompetisi sudah selesai maka selesai juga urusan kandidat terpilih dengan konstituennya, dalam persfektif sebagian besar anggota dewan bahkan juga masyarakat sebagian besar ketika habis berpolitik dalam pemilu maka selesai pula hubungan dengan masyarakat padahal mereka yang terpilih masih punya umpan balik kepada yang memilihnya.

Persfektif itu muncul disebabkan adanya ongkos politik yang mahal dan loyalitas yang berlebihan kepada masyarakat pemilih diwaktu pemilu berjalan seperti pemberian sarana infrastruktur yang belum waktunya, money politik, dan lainnya yang kesemuanya itu bertujuan agar masyarakat memilihnya seharusnya proses itu dilakukan dengan perang adu gagasan atau ide-ide untuk merubah pola pikir masyarakat agar maju serta berkembang maju. Akuntabilitas publik dewan bukan hanya terletak balas jasanya kepada konstituen memberikan sarana publik untuk kelangsungan dan kelancaran jalannya perekonomian diwilayahnya, akan tetapi bentuk transparansi, konsilidasi, serta pertanggungjawaban tentang apa saja yang sudah mereka perbuat untuk konstituennya. Jadi rakyat yang memilih bisa mengetahui seberapa besar kinerja wakilnya dan menjadi tolak ukur kesesuaian dengan kebutuhan didapilnya.

\section{Pembahasan}

\section{Bentuk Akuntabilitas Pemetaan Dewan Terhadap Konstituen}

Pada kalangan masyarakat terkadang tidak begitu banyak orang yang menyadari bahwa ongkos demokrasi itu mahal. Istilah ongkos tentu menyangkut beberapa aspek, yaitu sebagai biaya yang bernilai ekonomis. Rimbo Ilir sebagai Kecamatan yangt dapat memberikan suaranya dalam pemilu legislatif setidaknya mendapatkan input lewat pembangunan infrastruktur. Oleh beberapa kalangan politisi diarea legislatif Kabupaten Tebo telah diklaim oleh beberapa pihak sebagai Kecamatan yang kecil yang kurang memberikan pengaruh terhadap jalannya perekonomian di Kabupaten Tebo, dikarenakan wilayahnya yang berdekatan dengan Kabupaten Bungo sehingga aktivitas ekonomi dan perputaran uangnya banyak bergulir disana.

Sebagian besar dari biaya ini harus ditanggung secara personal oleh para calon pasangan pejabat ini. Anggota Dewan yang pada kontestasi pemilu mencalonkan diri memang harus siap dalam segala hal dan berbicara kembali mengenai ongkos politik terhitung mulai dari biaya resmi, setengah resmi, sampai tidak resmi, belum lagi jika pasangan ini harus menyewa konsultan politik yang mulai menjadi fenomena tersendiri. Biaya dipastikan akan makin meningkat seandainya urusan hasil pemilihan ini lalu mengalir menjadi sengketa. 
Pemetaan dalam wilayah dapilnya anggota DPRD mencakup semua wilayah dalam satu dapil tetapi disisi lain mereka tetap memprioritaskan yang merupakan basis pemilihan terbanyak. Penulis disini juga tentu berbicara lebih kepada realitas politik yang terjadi dilapangan bahwa pemetaan wilayah tersebut bukan sematamata kemauan individu terkait namun juga ada campur tangan dan kerja dengan para anggota lain demi kerja sama politik dan karier dimasa depan, mengapa bisa demikian karena sudah menjadi ketentuan dan pola pikir gagasan mereka mulai awal bagaimana dia bekerja untuk konstituen akan dinilai oleh basisnya tentang bagaimana langkah kedepannya. Maka dari itu pola pikir mereka ketika satu tahun menjabat pertama kali mereka sudah berfikir untuk periode ke duanya, itu pemikiran yang normal dan sewajarnya karena sifat politisi adalah akan ingin terus melegalkan kekuasasannya. Tentu itu sah-sah saja selagi selaku menjadi wakil rakyat bisa amanah, adil dan tidak diktator.

Jadi seharusnya proses akuntabilitas itu bisa dilaksanakan anggota atau individu anggota DPRD kepada konstituen demi mendapatkan tempat untuk periode keduanya karena lewat akuntabilitas kepada konstituen sesungguhnya mereka sudah melakukan umpan balik kepada konstituen sebagai benntuk pertanggungjawaban. Dapil II Kecamatan Rimbo Ilir yang memberikan suara terbanyak kepada kandidat Pahlepi dan Karno tentu juga apada ahirnya akan mendapatkan umpan balik dari mereka sekalipun sebagian besar lain ada yang memberikan suara terbanyak kepada kandidat dari luar Kecamatan Rimbo Ilir, tapi realitas anggota dari luar tersebut tentu lebih memihak dimana mereka tinggal berdomilisi. Berikut pemetaan dalam tabel anggota DPRD dapil II:

\begin{tabular}{|c|c|c|c|c|}
\hline \multicolumn{5}{|c|}{ Tabel 1. Data DPRD Dapil II Kabupaten Tebo } \\
\hline No & ANGGOTA DPRD & PARTAI & WILAYAH DAPIL II & ALAMAT \\
\hline 1 & Rosmalena & Golkar & $\begin{array}{l}\text { Kecamatan Tebo } \\
\text { Tengah, Rimbo Ilir, } \\
\text { Sumay. }\end{array}$ & $\begin{array}{l}\text { RT.001 RW.008 } \\
\text { Kel. Tebing Tinggi } \\
\text { Kec. Tebo Tengah }\end{array}$ \\
\hline 2 & Rudi Hartono S. Pd & Golkar & $\begin{array}{l}\text { Kecamatan Tebo } \\
\text { Tengah, Rimbo Ilir, } \\
\text { Sumay. }\end{array}$ & $\begin{array}{l}\text { RT002 RW.000 } \\
\text { Desa Suo Suo } \\
\text { Kec. Sumay }\end{array}$ \\
\hline 3 & Pahri & PDI P & $\begin{array}{l}\text { Kecamatan Tebo } \\
\text { Tengah, Rimbo Ilir, } \\
\text { Sumay. }\end{array}$ & $\begin{array}{l}\text { Dusun Tangkit RT.01 } \\
\text { Desa Punti Kalo } \\
\text { Kec. Sumay }\end{array}$ \\
\hline 4 & Pahlepi S. Pd. I & Demokrat & $\begin{array}{l}\text { Kecamatan Tebo } \\
\text { Tengah, Rimbo Ilir, } \\
\text { Sumay. }\end{array}$ & $\begin{array}{l}\text { Jl. Apel RT.010 } \\
\text { Desa Karang Dadi } \\
\text { Kec. Rimbo Ilir }\end{array}$ \\
\hline 5 & Karno, A.Md & Gerindra & $\begin{array}{l}\text { Kecamatan Tebo } \\
\text { Tengah, Rimbo Ilir, } \\
\text { Sumay. }\end{array}$ & $\begin{array}{l}\text { Jl. Lada RT. } 003 \text { RW.002 } \\
\text { Desa Sumber Agung Kec. } \\
\text { Rimbo Ilir }\end{array}$ \\
\hline 6 & Darul Kutni & PKB & $\begin{array}{l}\text { Kecamatan Tebo } \\
\text { Tengah, Rimbo Ilir, } \\
\text { Sumay. }\end{array}$ & $\begin{array}{l}\text { RT.003 Desa Punti Kalo } \\
\text { Kec. Sumay }\end{array}$ \\
\hline 7 & Husni Fahri & Nasdem & $\begin{array}{l}\text { Kecamatan Tebo } \\
\text { Tengah, Rimbo Ilir, } \\
\text { Sumay. }\end{array}$ & $\begin{array}{l}\text { RT.004 Bedaro Rampak } \\
\text { Kec. Tebo Tengah }\end{array}$ \\
\hline
\end{tabular}

Sumber: Sekretariat DPRD Kabupaten Tebo

Dari tabel diatas bisa dilihat bahwa 5 anggota lain berdomisili dan tinggal diluar Kecamatan Rimbo Ilir, itulah maksud dari penjelasan sebelumnya bahwa mereka (anggota) DPRD hanya akan melakukan umpan balik kepada suara terbanyak yaitu diwilayah mereka tinggal. Merupakan sebuah bentuk umpan balik dari anggota DPRD kepada wakil konstituen meskipun secara pemerataan dan 
keadilan dalam menyerap serta merealisasikan aspirasi didaerah pilihannya tidak produktif dan tercapai. Pada persoalan itulah terkadang anggapan dimasyarakat yang muncul perlu dibenarkan, bahwa stikma yang muncul setiap perwakilan dilegislatif mampu mengabulkan serta mengakomodir seluruh aspirasi yang jadi kehendak masyarakat bawah. Para anggota tetap mempunyai porsi sendiri-sendiri apalagi jumlah penduduk/luas wilayah dirimbo ilir yang kecil harus disesuaikan dengan prioritas utama dibanggar tingkat kabupaten. Disini sebenarnya dewan juga bukan eksekutor utama dalam mewujudkan pembangunan karena ada bupati selaku leding sector utama.

Ada beberapa hal yang sebenarnya menjadi alasan pokok tentang akuntabilitas atau umpan balik anggota DPRD kepada konstituen yang jadi titik dasar bahwa itu dirasa tidak seberapa penting dilakukan, karena dimasa pemilu dulu mereka sudah banyak berjuang mengeluarkan biaya yang cukup besar atau yang disebut ongkos politik. Walaupun secara aturan hal itu tidak ada kaitannya tetapi politik juga mengenal untung rugi yang dalam realitanya bisa kita saksikan sama-sama setiap kontestasi yang muncul pasti mereka loyalitas kepada wiliyah dapilnya tinggi agar terpilih untuk mengumpulkan suara yang cukup banyak, yang berbanding terbalik ketika mereka sudah resmi menjabat gantian partai politiknya yang jadi loyalitas utama.

\section{Bentuk Akuntabilitas Anggota DPRD Dapil II Kecamatan Rimbo Ilir Kabupaten Tebo terhadap konstituennya paska terpilih dipemilu legislative}

\section{Menjalin Komunikasi Dengan Konstituen}

Rimbo Ilir adalah sebuah Kecamatan yang mayoritas berisi penduduk suku jawa yang setiap ada kontestasi pemilu tingkat legislatif sebelum periode 2014 tidak terlalu dianggap mempunyai kontribusi penting dalam menggali suaranya juga dari sisi masyarakatnya. Itu bisa terjadi karena wilayah basis Rimbo Ilir yang ketika itu masi bergabung dengan dapil Rimbo Bujang rata-rata memberikan suara politiknya terhadap kandidat yang berbeda-beda, dikarenakan kala itu tidak pernah mempunyai kandidat lokal yang yang muncul ataupun dalam arti lain masyarakatnya masih mudah cenderung diarahkan dan belum mempunyai prinsip pilihan politik yang kukuh.

Berkaitan dengan akuntabilitas publik dimana pada saat ini pada priode 2014-2019 Kecamatan Rimbo Ilir ketika pemilu lalu masuk dapil II bersama Kecamatan Tebo Tengah dan Kecamatan Sumay telah menempatkan 7 orang anggota dewan yang berhasil memenangkan pemilu legislatif.

Salah satu ekspestasi pemilih adalah tersalurkannya aspirasi mereka melalui anggota legislatif yang mereka pilih. Dalam esensi wawacara diatas adalah sebuah pernyataan tentang adanya kumunikasi antara pihak konstituen dengan wakilnya, tetapi bukan hanya sekedar itu akuntabilitas anggota DPRD seharusnya bisa memuat sebagai wadah tempat pengaduan atau ruang publik untuk berdiskusi. Waktu khusus yang diperuntukkan bagi anggota DPRD dan musyawarah rencana pembangunan (musrenbang) pada tatanan birokrasi pemerintah juga harus diimbang dengan mekanisme yang dikembangkan didalam partai politik dalam menyerap aspirasi konstituennya.

Fungsi menyerap, memperjuangkan, dan menyampaikan aspirasi kontituen partai politik oleh anggota legislatif merupakan salah satu yang harus dijalankan sesuai dengan kerja partai politik. Realitas politik yang berkembang saat ini mengisyaratkan kandidat terpilih harus bisa menyerap aspirasi dengan memanfaatkan masa reses dan saat-saat melakukan kunjungan kerja ke daerah pilihannya. Anggota DPRD telah melakukan 
komunikasi politik dengan masyarakat meskipun kuminikasi yang dilakukan tidaklah seperti yang diinginkan, dalam pelaksanaan kuminikasi anggota DPRD dengan konstituen banyak sekali masukan-masukan dari masyarakat yang dapat dijadikan bahan pertimbangan bagi pemerintah dalam membuat kebijakan. Sehingga kebijakan yang dibuat tetap sasaran dan tepat guna, ada beberapa permasalahan yang dihadapi dalam melakukan kumunikasi politik diantaranya berkenaan dengan masalah waktu diadakannya kumunikasi politik dengan masyarakat, partisipasi masyarakat, dana yang terbatas dalam merealisasikan pembangunan. Sehingga berdampak pada anggota DPRD dalam kumunikasi politik yang dianggap tidak aspiratif. Anggota DPRD harus selalu melakukan komunikasi yang efektif dengan kontituennya, karena dalam sistim politik lokal yang mengakibatkan aspirasi dan kepentingan konstituen tidak terwujud.

Agar memperoleh jawaban yang seimbang sebagai bahan pembanding maka penulis disini juga akan mengajukan pertanyaan yang sama kepada anggota DPRD lain yang juga mewakili dapil II Kecamatan Rimbo Ilir. Ketika kampanye seorang kandidat sedang bersosialisai dan kemudian menyerap aspirasi dari masyarakat bawah kemudian ketika ia terpilih konstituen menagihnya. Tapi setelah ia terpilih aktivitas intens kepada konstituen tetap dilakukan karena masyarakat perlu mengetahui pencapaian pokoknya. Menindaklanjuti aspirasi masyarakat, sesungguhnya dapat dijadikan indikator bagi tumbuh dan berkembangnya iklim demokrasi di suatu dapil, tapi realitas justru sebagian besar masyarakat khususnya di Rimbo Ilir kurang peduli dengan keadaan itu mereka enggan mempermasalahkan hal demikian jika pemilu selesai maka selesailah urusnya kepada calon. Padahal mereka masih akan mendapatkan hak-hak dari apa yang mereka pilih.

Penerimaan aspirasi masyarakat itu tidak hanya terbatas di gedung DPRD serta pada saat berlangsungnya Raker, tapi dapat dilakukan dimana saja bahkan lebih dekat dengan tempat dan permasalahan di mana masyarakat berada. Serap aspirasi pada masa reses, sesungguhnya merupakan bentuk aktif wakil rakyat di DPRD untuk mendengarkan dan melihat permasalahan, harapan, keinginan dan kritik masyarakat terhadap kebijakan pembangunan yang dijalankan oleh Pemerintah Daerah. Kekuatan menyerap aspirasi ini terletak dari seberapa besar anggota Dewan mampu melakukan perbandingan dan solusi atas kebijakan yang ditetapkan Pemerintah Daerah dengan permasalahan yang dihadapi masyarakat. Aspirasi masyarakat dapat dijadikan salah satu materi pokok bagi anggota DPRD untuk melaksanakan fungsi pengawasan dalam rangka menyempurnakan atau mengoreksi kebijakan pembangunan yang ditetapkan Pemerintah Daerah.

Disamping itu tentu ada hal yang agak dilema bagi anggota DPRD kepada konstituen, jika pemerintah sudah menetapkan program prioritas tetapi program tersebut tidak sesuai dengan aspirasi didapilnya maka menjadi sia-sia karena biar bagaimanapun kesepakatan terbanyaklah yang dimenangkan. Maka saran penulis adalah seharusnya anggota DPRD yang berasal dari dapil II Kabupaten Tebo mampu berkompromi untuk mempurjuangan dapilnya sesuai porsinya dan dimana mereka berdomisili, namun hal itu terkendala oleh bendera partai yang berbeda. Kompromi dalam hal ini tentu saja bentuk kompromi atau konsilidasi yang mendukung pembangunan didapil II Kecamatan Rimbo Ilir. Sumay, dan Tebo Tengah.

Penjadwalan agenda dalam menyerap aspirasi pada masa reses, tidak boleh dijadikan alasan bagi anggota DPRD untuk tidak berpihak dan tidak maksimal dalam memperjuangkan aspirasi masyarakat. Satu tugas penting 
yang harus terus dilakukan anggota DPRD Dapil II Rimbo Ilir yaitu memperbaiki kesalahan persepsi sebagian masyarakat yang menyatakan kegiatan menyerap aspirasi itu identik dengan keharusan untuk membagikan uang kepada masyarakat. Kepuasan masyarakat terhadap wakilnya di DPRD justru harus dibuktikan dengan kinerja yang maksimal dan kemampuan anggota DPRD Dapil II Rimbo Ilir untuk menerima aspirasi masyarakat. Strategi dan interaksi komunikasi anggota DPRD harus benarbenar menyuarakan keinginan dan harapan masyarakat yang diwakilinya.

Realitas dalam hasil wawancara diatas singkron dengan keadaan dilapangan, memang jika penulis liat ada dua jenis karakteristik tim pemenangan dalam mengusung atau mendukung calonnya. Motif yang pertama sudah tentu adalah iming-iming uang dari kandidat yang realitas pada umumnya ketua tim pemenangan diberikan tugas untuk mengelola itu dan biasanya vee atau anggaran yang diterima dalam jumlah yang banyak. Maka tidak heran kandidat yang cukup banyak mempunyai modal yang pada umunya dari kalangan pengusaha, bisnis, dan lainnya maka akan sangat mudah untuk memperoleh dukungan daripada calon dari akademisi walaupun dukungan itu tidak murni menjamin kemenangan. Motif kedua adalah ketua tim pemenangan bener-benar mendukung karena menginginkan perubahan dan ada yang diharapakan dari calonnya ketika kelak ia duduk dianggap dapat memenuhi aspirasinya tanpa barter politik ataupun kontrak politik.

Penerimaan aspirasi masyarakat harusnya dibuktikan berdasarkan program kerja dan pernyataan-pernyataan politik anggota dari dapil II yang berpihak kepada rakyat. Hasil kerja anggota DPRD dapil II dalam menerima aspirasi masyarakat, perlu secara tepat menjawab berbagai kepentingan yang memang dibutuhkan dan diharapkan oleh masyarakat. Kedekatan hasil kerja wakil rakyat dengan banyak harapan agar hal balas jasa dilakukan dengan bekerja keras karena telah dipilih supaya tidak lepas tangan karena ada pemikiran bagi anggota DPRD dapil II yang membagi-bagikan uang saat melakukan kampanye dahulu jika hal itu benar dilakukan. Bukan hal yang sangat rahasia lagi bila hal demikian telah dilakukan tetapi menurut analisa penulis tentu saja setiap individu kandidat tidak melakuakan sama-sama dengan skala yang besar dan laus karena tidak semua kandidat mempunyai begron, usaha. dan kemampuan finansial yang sama.

\section{Membentuk Wadah Untuk Menyerap Aspirasi}

Setiap masing-masing individu dari anggota dewan dalam menyerap aspirasi tentu mempunyai cara-cara sendiri-sendiri. Menurut pemikiran penulis seharusnya pelaksanaan komunikasi politik dalam menyerap aspirasi yang dilakukan oleh anggota dewan dilakukan dengan cara berdialog secara langsung, dalam satu ruangan mereka membicarakan tentang bagaimana aspirasi yang masyarakat/perwakilan tokohnya sampaikan agar dapat mereka realisasikan. Lalu masyarakat Rimbo Ilir meminta kepada anggota dewan dapil II untuk memperhatikan kebutuhan social masyarakat, terutama berkenaan dengan peningkatan pelayanan publik yang tidak berbelit-belit, pendidikan, dan akses transportasi yang selama ini masih ada jalan-jalan yang belum mendapatkan perhatian dari pemerintah, paling tidak sarana trasportasi ini bisa mempelancar masyarakat untuk melakukan aktifitas baik untuk menuju kekota, memperlancar dalam hal mengangkut hasil perkebunan dan membuka akses bagi masyarakat yang mau berkunjuung kedesa-desa lainnya. Sehingga tidak ada lagi masyarakat merasa terisolir atau terkucilkan. 
Dialog dan tatap muka adalah cara yang efektif dalam mengetahui secara langsung apa yang diinginkan oleh masyarakat. Dalam pertemuan dengan masyarakat akan terungkap apa yang menjadi persoalan di tengah masyarakat, misalnya masalah kesehatan, pendidikan, akses transportasi (jalan), keterbelakangan sarana pendidikan atau masalah lain yang sangat diperlukan sekali oleh masyarakat Kecamatan Rimbo Ilir. Sudah seharusnya anggota DPRD dapil II mendapatkan informasi langsung dari masyarakat, jadi mereka dapat mendengar aspirasi, keluhan dan keinginan masyarakat.

3. Pemanfaatan Masa Reses untuk berdialog dengan masyarakat

Berkenaan dengan masa reses ini tentunya harus di sediakan waktu khusus untuk bertemu dengan konstituen agar dalam pelaksanaan reses dapat bertemu dengan masyarakat di mana desa yang di kunjungi anggota Dewan. Berdasarkan wawancara dengan informan di peroleh informasi bahwa, waktu atau jadwal yang telah di tetapkan untuk reses kelapangan kadang menjadi kendala ada saja kegiatan mendadak, misalnya kita harus menghadiri rapat atau kunjungan keluar daerah, kedatangan tamu dari luar daerah, dan menghadiri acara yang tidak dapat di tinggalkan, karena undangan atau acara datangnya tidak dapat kita jadwalkan, yang akhirnya jadwal yang di rencanakan untuk bertemu dengan konstituen tertunda, tentu ini akan berdampak kepada kekecewaan masyarakat dimana daerah yang akan di kunjungi, sehingga masyaraka beranggapan bahwa anggota dewan ingkar janji, anggota Dewan tidak mau datang dan sebagainya, karena jauh sebelum berkunjung, kita meminta pihak aparatur di tinggkat Kecamatan dan desa untuk mempersiapkan sesuatu dan mengundang masyarakat dalam pertemuan yang telah di jadwalkan.

Selain itu sehubungan dengan pembuatan perda-perda didaerah yang banyak dibahas juga membuat anggota dewan tersandara untuk berhubungan dengan konstituen. Berdasarkan informasi di atas dapat di simpulkan sementara bahwa waktu berkunjung kelapangan untuk bertemu dengan konstituen merupakan salah satu faktor penghambat untuk melakukan komunikasi politik kepada konstituen. Kalaupun waktu yang di sediakan sedikit anggota Dewan harus bisa membagi-bagi waktunya untuk dapat melakukan komunikasi politik dengan konstituen, dalam arti memanfaatkan waktu yang relative singkat untuk dapat berkomunikasi dan memperoleh hasil dari pelaksanaan reses tersebut, minimal keluhan masyarakat akan kebutuhannya yang kemudian dapat di jadikan bahan untuk membuat kebijakan bersama eksekutif untuk menanggulangi permaslaahan yang menjadi keputuhan pokok masyarakat setempat.

\section{Faktor Penghambat Anggota DPRD Dalam Pelaksanaan Akuntabilitas Publik Terhadap Konstituen}

\section{a. Tingkat Partisipasi Masyarakat Rendah}

Berdasarkan wawancara dari tokoh masyarakat terungkap fakta bahwa, kurangnya partisipasi masyarakat ketika selesai pemilu legislatif masyarakat merasa sudah selesai pertanggungjawaban wakilnya. Jika anggota dewan merasa tidak sanggup dalam merealisasikan aspirasi masyarakat, sebaiknya anggota dewan tidak memberikan harapan atau janji-janji kepada masyarakat, karena hal itu akan menjadi momok sendiri bagi anggota dewan ketika datang kembali menemui masyarakat.

Bagaimana reaksi atau empati masyarakat setelah wakilnya dilegislatif sudah bekerja? (Riyadi, Wawancara, 2018)

Masyarakat berfikir bahwa partisipasi atau suasana yang rame diperbincangkan adalah saat menjelang atau sedang pemilu saja, rata rata 
mereka sudah lupa jika berjalannya waktu anggota dewan terpilih sedang bekerja untuk dapilnya pada masa jabatannya, padahal itu inti dari kinerja yang diberikan karena kita semua sudah memilihnya. (Riyadi, Wawancara, 21-05-2018).

Pada masa jabatan anggota dewan sedang berjalan seharusnya hubungan dengan konstituen lebih dibina lagi agar masyarakat dapat mengerti tingkat tolak ukur kinerjanya. Itu bisa dilakukan sekaligus guna menghidupkan partisipasi masyarakat yang rendah, namun jika anggota dewan tetap berhenti disebatas itu dan masyarakat yang tidak tau atas kinerja yang dibuatnya, indikasinya tidak menutup kemungkinan anggota dewan itu tidak akan mendapatkan dukungan kembali oleh konstituen jika mencalonkan anggota DPRD pada periode berikutnya, karena keberadaan anggota DPRD di parlemen sangat ditentukan oleh pendukungnya atau konstituen dimana mereka mencalonkan. Jadi masyarakat menjadi enggan atau tidak berempati lagi terhadap jalannya pemilu legislatif bahkan kepada wakilnya sendiri karena merasa dibohongi, sehingga jalannya komunikasi kepada konstituen menjadi terhambat.

b. Dana Yang Terbatas Dari Pemerintah

Dalam merealisasikan pembangunan ketika melakukan komunikasi untuk berbicara tentang kebijakan yang berujung pada komunikasi politik, anggota DPRD harus dapat meyakinkan kepada masyarakat bahwa apa yang diinginkan oleh masyarakat dapat atau tidak untuk dilaksanakan. Banyak faktor yang merupakan penghambat bagaimana sebuah aspirasi masyarakat terbuang ketika dalam perumusan kebijakan publik dalam APBD, karena dalam pembahasan anggaran yang pada semulanya di masukan program-prgram yang berkaitan dengan kepentingan orang banyak, misalnya berkenaan dengan sarana dan prasarana, karena untuk merealisasikan keinginan masyarakat memerlukan dana yang tidak kecil, sehingga ketika anggota Dewan menyampaikan keinginan masyarakat banyak yang tidak dapat di realisasikan karena terbentur dengan kemampuan keuangan daerah atau faktor kompromi politik didewan. Yang menjadi masalah adalah ketika masukan atau informasi atau permintaan dari masyarakat tersebut tidak dapat diwujudkan karena alasan anggaran daerah tidak mencukupi untuk menampung aspirasi masyarakat yang masuk melalui DPRD dan telah DPRD sampaikan, karena pemerintah daerah dalam membahas anggaran lebih kepada rumusan skala prioritas untuk mengimbangi kemampuan keuangan daerah. Tetapi masyarakat tidak mengerti tentang mengapa tuntutan mereka yang mereka sampaikan tidak dapat dilaksanakan.

\section{Tindak Lanjut Anggota DPRD Dari Dapil II Kecamatan Rimbo Ilir Kab.Tebo Atas Janji Politik Serta Kontrak Politik Mereka Terhadap Konstituen}

Berbicara mengenai tindak lanjut anggota DPRD Dapil II Kabupaten Tebo setelah terpilih tentu mereka gantian melakukan umpan balik kepada konstituennya. Kata kata yang juga sering ditemui yaitu semacam balas jasa atau kepercayaan karena mereka yang terpilih telah diberi amanah untuk memperjuangkan aspirasi didapilnya.

Jadi hubungan dengan kontituen bukan pada saat mereka tidak bisa hanya sekedar janji saja padahal diwaktu masa pemilu mereka cukup meyakinkan publik dengan banyak melakukan upaya-upaya seperti janji politik atau kontrak politik. Masyarakat terkadang juga memberikan tuntutan-tuntutan agar asprasinya benarbenar dipenuhi lalu beberapa diantara mereka mencoba mencari pegangan, yang 
antara lain dilakukan dengan meminta calon menandatangani dokumen yang populer disebut "kontrak politik".

Sudut pandang pemikiran diatas adalah sebuah ketakutan akan resiko yang dialami, semisal bila kontrak politik dilaksanakan dengan program yang mempunyai nilai kontrak nominal yang besar dan itu ketika yang bersangkutan menjabat tidak berhasil merealisasikannya, maka apa yang sudah tertulis pada hitam diatas putih tersebut yang biasanya disepakati oleh tokoh masyarakat setempat serta team pemenangan maka anggota dewan yang bersangkutan akan dianggap ingkar dan tentu tidak akan memperoleh simpati publik lagi dimasa pemilihan mendatang.

Menindaklanjuti masalah keabsahan atau legalitas dalam kontrak politik sekalipun demikian bukan berarti tidak ada kontrak dalam hukum publik. Di dalam ranah hukum publikpun dimungkinkan dilakukan kontrak sebagaimana misalnya terjadi pada area hukum internasional. Perjanjian-perjanjian internasional, semacam traktat, konvensi, atau fakta yang dibuat oleh institusi publik sebagai subjek hukum internasional, adalah suatu kontrak dalam area hukum publik. Hanya saja, tidak tepat untuk menyebut janji seorang calon pejabat publik menjelang pemilihan sebagai suatu bentuk kontrak, baik dalam hukum perdata maupun publik.

Mengingat janji-janji calon pejabat publik juga sering ditayangkan dalam bentuk iklan, menarik juga untuk mengamati apakah konsep ini bisa digunakan sebagai dalih menuntut ganti-rugi atas kegagalan pemenuhan janji kontrak. Namun untuk urusan pemilu legislatif tingkat Kabupaten hal ini tidak terlalu menjadi hal yang serius apalagi melihat kultur masyarakat Rimbo Ilir yang tidak banyak peduli tentang isu atau masalah public seperti ini, sekali lagi penulis menjelaskan mereka memiliki pemikiran yang ketika pemilu sudah selesai maka selesai sudah urusan mereka dengan kandidat tersebut. Penjelasan serta wacana diatas adalah merupakan bentuk tekanan kepada publik agar ada jaminan mereka memberikan suara pilihan atas iming-iming yang sudah diberikan. Persoalannya adalah ketika kandidat memberikan argumentasi berupa ide-ide dan gagasan dalam membangun sebenernya mereka tidak terlalu yakin hal itu dapat menjual atau mendapatkan empati lebih dimasyarakat, sehingga cara-cara yang tidak lazim kadang dilakukan.

Polemik diatas dalam penjelasan informan kepada tokoh masyarakat benar adanya. Cara cara yang demikian sudah lazim dilaksanakan walaupun dari sisi etika bertolak dengan tata cara berkampanye, atau dalam istilah yang disebut take and give yang berarti ada umpan balik antara konstituen yang memilih terhadap wakilnya kelak di DPRD. Kontrak dalamnya tentu membutuhkan kejelasan subjeksubjeknya, bukan sekedar anda butuh apa dan kapan. Juga harus jelas distribusi hak dan kewajibannya, sebagai contoh, kandidat pernah berjanji untuk membangun gardu pembangkit listrik beserta jaringannya di Desa jalur A dalam 3 tahun masa jabatannya terpilih. Lalu pasangan ini gugur terpilih, bila ini terjanji tentu saja membuktikan pola pikir masyarakat yang modern tidak mudah dimobilisasi serta sebagai bukti bahwa rakyat masyarakat tidak lagi percaya dengan janji iming-iming seperti ini.

Jika sebaliknya masyarakat mengiyakan berarti kekuatan uang dalam kompetisi politik makin susah dielakkan atau dihapuskan paradigma tersebut diera demokrasi ini. Sekali lagi bahwa juanji politik ini tidak memiliki ikatan secara hukum. Andaikata ada draf kontrak yang dibuat dan ditandatangani oleh calon kandidat, tetap patut dipertanyakan siapa-siapa saja yang terlibat dalam perjanjian ini. Siapa rakyat yang dimaksud? Apakah rakyat Rimbo Ilir cukup terwakili? Jika terwakili, apakah tolok ukuranya mereka itu sebagai wakil rakyat? Kedua, soal kecakapan. Kerap terjadi di dalam "kontrak politik" seperti ini, subjek yang 
melakukan kontrak itu tidak dapat dibebani kewajiban hukum guna memenuhi janjinya. Alasan yang paling jelas adalah karena untuk mewujudkan secara kongkret janji-janjinya, kerap diperlukan otoritas lain di luar dari subjek.

Selanjutnya, janji-janji semacam klaim bakal mampu mengatasi aspirasi dan keluhan publik dalam tiga tahun merupakan janji yang terlalu umum. Orang akan gampang berkilah, tidak sesuai dengan porsi RAB atau anggaran APBD dan lainnya. Sebenarnya masyarakat dapat dengan jelas mengatakan bahwa kontrak politik dengan imbalan suara pemilih di saat hari pencoblosan merupakan sebuah transaksi yang tidak halal secara hukum. Oleh sebab itu, pada hakikatnya "kontrak politik" adalah sekedar janji yang mengikat secara moral. Walaupun ada istilah bahwa janji adalah hutang, pada kenyataannya hutang ini tidak dapat dieksekusi secara legal. Jadi, rakyat seharusnya tidak gampang terperdaya oleh janji manis para calon pejabat publik, apalagi jika janji itu diucapkan di luar jangkauan akal sehat kita.

\section{Hasil Tindak Lanjut dari janji politik serta kontrak politik Yang Terlaksana Dan Belum Terlaksana}

Selama kurun waktu 4 tahun lebih jabatan anggota DPRD Kabupaten Tebo dapil II tentu ada beberapa program hasil tindak lanjut dari program yang sudah terlaksana ataupun belum terlaksana. Karena tidak mungkin selama jabatannya Dewan tidak berbuat apa-apa untuk konstituennya dan sebaliknya pula tidak akan mungkin semua aspirasi ditingkat bawah dapat ditindak lanjuti. Untuk Dapil II Kecamatan Rimbo Ilir ada beberapa program yang sudah berhasil ditindaklanjuti diantaranya pembangunan di Desa Karang Dadi berupa sekolah madrasah, drainase sepanjang $150 \mathrm{~m}$, pengecoran jalan sepanjang $200 \mathrm{~m}$, penambahan lokal dan pagar sekolah, dan lampu jalan sebanyak 60 titik. Sementara di Desa Sido Rejo berupa pembangunan drainase sepanjang $100 \mathrm{~m}$, dan penambahan gedung di sekolah TK, Desa Giripurno berupa lampu jalan sebanyak 10 titik serta pengaspalan jalan sepanjang $1 \mathrm{~km}$, Untuk Desa Sumber Agung berupa pemberian satu unit mobil ambulance, penambahan gedung ditingkat SD, Madrasah, dan SMK, Desa Sepakat Bersatu yaitu pembebasan lahan untuk akses jalan baru menuju Desa Giri Winangun.

Terlepas sukses atau tidaknya program usulan anggota Dewan seharusnya tetap punya pertanggungjawaban kepada konstituen guna tranparansi bahwa mereka saat ini belum bisa melaksanakan tuntutan program A dan sementara diganti dengan tuntutan program $B$ terlebih dahulu atau dengan kata lain alternatif aspirasi dari konstituen tidak segalanya terwujud. Dalam makna yang sebenarnya esensinya adalah pada bentuk pertanggungjawaban anggota DPRD untuk melaporkan hasil kinerjanya kepada kontituen.

Bedasarkan analisa diatas yang memuat informan dari tokoh masyarakat dan tim pemenanagan bahwa tentang akuntabilitas anggota DPRD yang mempunyai output pembangunan serta bentuk sarana publik baik fisik maupun non fisik dapat diambil titik ketidakpuasan masyarakat antara realita dengan harapan lewat aspirasi mereka. Menurut sudut pandang masyarakat bahwa seharusnya perwakilan mereka dilegislatif dapat bertindak lebih untuk mewujudkan aspirasi mereka dalam pola pikir kalkulasi sebagian masyarakat dapil II Kecamatan Rimbo Ilir merasa bahwa selama priode ini belum ada yang signifikan dalam pemerataan pembangunan. Harapan yang besar serta ketergantungan masyarakat pada priode 2014-2019 adalah partisipasi terbesar mereka terhadap kandidat dengan terbukti mampu mendudukkan dua calonnya dari Kecamatan Rimbo Ilir, namun tetap saja masih dianggap minim kinerjanya.

Sementara tindak lanjut yang tidak atau belum terlaksana berupa penambahan jaringan listrik di Dusun Kopra Desa Sepakat Bersatu, pengecoran 
akses jalan menuju SD, penambahan jaringan travo PLN, Aspal penghubung jalan lingkar Desa Giripurno, penambahan gedung sekolahan, pembuatan TPA, pembanguan gedung seni dan bangunan Bok Jembatan di Desa Pulung Rejo.

\section{Penutup}

Kesimpulan dari penelitian ini adalah 1) bentuk akuntabiliatas publik anggota DPRD dapil II Kecamatan Rimbo Ilir Kabupaten Tebo antara lain a. Menjalin Komunikasi dengan konstituen; b. Membentuk wadah untuk menyerap aspirasi; c. Pemanfaatan masa reses untuk berdialog dengan masyarakat; d. Peran anggota DPRD kepada partai. 2) Faktor penghambat anggota DPRD dalam menjalankan akuntabilitas publik kepada konstutuen adalah a. Tingkat partisipasi mesyarakat rendah; b. Dana yang terbatas dari pemerintah. 3) Tindak lanjut anggota DPRD Dapil II Kecamatan Rimbo Ilir membawa tuntutan dibasis wilayah pilihan yang tertuang didalam usulan yang disepakati dalam rancangan anggaran biaya. Namun demikian program tetap diadu agar skala priotas utama mencapai kesepakatan disitulah letak perjuangan Dewan agar tindak lanjutnya disepakati dalam musyawarah atas dasar kompromi/kesepakatan bersama. Terlepas sukses atau tidaknya program usulan anggota Dewan seharusnya tetap punya pertanggungjawaban kepada konstituen guna transparansi bahwa mereka saat ini belum bisa melaksanakan tuntutan program. Dalam makna yang sebenarnya esensinya adalah pada bentuk pertanggungjawaban anggota DPRD untuk melaporkan hasil kinerjanya kepada kontituen.

Berikut adalah beberapa saran 1) Proses akuntabilitas publik Anggota DPRD kepada konstituen adalah bentuk transparansi serta pertanggungjawaban selama menjabat, jadi anggota dewan seharusnya mampu membuat sistem target kinerja kepada konstituen atas semua aspirasi maupun janji politiknya dapat diketahui masyarakat sehingga masyarakat mengerti tolak ukurnya. 2) Kontrak atau janji politik yang dilakukan Anggota DPRD seharusnya tidak dijadikan media untuk menarik suara publik, karena tidak adanya landasan hukum yang mengatur untuk dijadikan tuntutan, pihak tokoh masyarakat ataupun tim pemenangan harus cerdas dalam mensosialisasikan kandidatnya karena tidak semua aspirasi masyarakat menjadi program prioritas masyarakat. 3) Partai politik juga harus memberikan tolak ukur terhadap kadernya yang duduk menjabat sebagai Anggota DPRD tentang kinerjanya kepada konstituen agar memprioritaskan didaerah pilihannya meskipun didalam keterkaitannya kepada konstituen. 4) Menurut pemikiran penulis seharusnya pelaksanaan komunikasi politik dalam menyerap aspirasi yang dilakukan oleh anggota dewan dilakukan dengan cara berdialog secara langsung, dalam satu ruangan mereka membicarakan tentang bagaimana aspirasi yang masyarakat/perwakilan tokohnya sampaikan agar dapat mereka realisasikan.

\section{Referensi}

Halim, Abdul. (2004). Akuntansi Keuangan Daerah, Penerbit Salemba Empat, Jakarta.

Adi, Isbandi Rukminto. (2019).Kesejahteraan Sosial (Pekerjaan Sosial, Pembangunan. Sosial, dan

kajian Pembangunan), Depok: Rajawali Pers

Agung Kurniawan. (2005). Transformasi Pelayanan Publik. Pembaharuan, Yogyakarta.

Amandemen Undang-Undang Pemda/ UU RINo. 92015

BKKBN. (2002). Buku Sumber untuk Advokasi

Djunaidi, Ghony. (2012). Metode Penelitian Kuantitatif, M. Djunaidi Ghony \&Fauzan Almanshur Jogjakarta, Al-Ruzz Media, Depok.

Iksan Darmawan.(2013). Analisis Sistem Politik Indonesia” Bandung. 
Kholmi, M. (2011). Akuntabilitas dalam perspektif teori agensi. Jurnal Ekonomika Bisnis, 2(2), 357-369.

Miriam Budiardjo.(2008). Dasar - dasarIlmuPolitik,GramediaPustakaUtama, Jakarta.

Nasikun. (2012). Sistim Sosial Indonesia. Jakarta.

Sadjiarto, A. (2000). Akuntabilitas dan pengukuran kinerja pemerintahan. Jurnal Akuntansi Dan Keuangan, 2(2), 138-150.

Pasal 1 angka 16 UU Nomor 10 Tahun 2008 Tentang Pemilihan Umum Anggota Dewan Perwakilan Rakyat, Dewan Perwakilan Daerah, Dan Dewan Perwakilan Rakyat Daerah Sinar Grafika.(2014). Adminitrasi Kependudukan Dan Pemerintahan, Jakarta. Sindung Haryanto. (2012). Spektrum Teori Sosial Dari Klasik Hingga Postmodern. Jogjakarta. Sugiyono. (2012). Metode Penelitian Kuantitatif, Kualitatif, Dan R\&D, Alfabeta, Bandung. Undang-Undang Republik Indonesia Nomor 8 Tahun 2012

Wicaksono, K. W. (2015). Akuntabilitas organisasi sektor publik. JKAP (Jurnal Kebijakan Dan Administrasi Publik), 19(1), 17-26. 